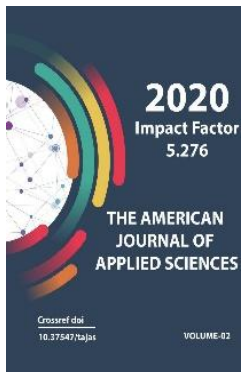

\title{
On The Issues Of Central Asian Turkish Versions And Literal Translation Of The Epic Poem «Ashyk Najep»
}

\author{
Jepbarova Sayat Kurbanmuratovna
}

Assistant Of The Department Of Turkmen Language And Literature Of Karakalpak State University, Nukus City Of The Republic Of Karakalpakstan, Uzbekistan

\section{Journal Website:}

http://usajournalshub.c

om/index,php/tajas

Copyright: Original content from this work may be used under the terms of the creative commons attributes 4.0 licence.

\section{ABSTRACT}

This article discusses the Central Asian Turkic versions of the epic "Ashyk Najep", their study and the implementation of the epic. At the same time, the issues of literary translation of the epic into other Russian and Turkish languages are studied. Differences in versions are identified.

\section{KEYWORDS}

Epic, version, bakhsy, variant, plot, composition

\section{INTRODUCTION}

Nowadays, in our country, we are paying more attention on ancient customs and traditions and baksy-musicians' field, so it is very important to be familiar with the poem "Ashyk Najep" too. Widening the poems which express real customs of our nation taking into account the necessities of the youth and life requirements and learning them based on the most actual theoretical 
conceptions of the world is one of the main problems of folklore.

The author of the poem "Ashyk Najep" is unknown and it is anonym poem. Main idea of the poem expresses the respect of the nation to music, music skills and baksy-jiraws. For this reason, events in the poem "Ashyk Najep" which was made to improve the power of the music art are portrayed widely by the main character Ashyk Aydin pyr, Albent, baksy Najep. This epic poem was called "Oshik Najab" in Uzbek folklore, "Najep uglan", "Ashik Najep" among Karakalpaks, "Nejep oglan" in Turkmen folklore.

This poem has been researched in the folklore of Turkish nations too. For example, this poem is called "Oshik Najab" in Uzbek folklore. Especially, this poem is widely known in Khorezm region. Thus, professor Saparbay Ruzimbaev wrote down the poem "Oshik Najab" from baksis and announced it in the 4th part of the multipart book called "Khorezm poems ", "Oshiknoma" in Urgensh, 2009. According to professor S.Ruzimbetov's opinion oral version of the poem "Oshik Najab" is found in baksi Ruzimbek Muratov's repertory. Uzbek version of the poem which was prepared for printing by professor S.Ruzimbetov defines that it was written down from Ugiljan khalfa who lives in the village Kushkupri, Khorezm region.

\section{MATERIALS AND METHODS}

In the work of professor K.Maksetov called "Qaraqalpaq xaliq awizeki do'retpeleri" (Karakalpak national oral works)(Nukus, 1996) in Karakalpak folklore, it was mentioned that the poem was particularly about musicians. According to scientist K.Maksetov, "The epic poem might have become known at the beginning of XIX among Karakalpaks and the source of it is Turkmen baksys without doubt.
At those times, Turkmen and Karakalpak baksys lived in the areas of Tashawiz and Gone Urgensh from one side and played decisive role in strong relationship from the other side. The epic poem «Ashyk Najep» had a remarkable place in Berdakh and his daughter Khurliman's repertoire as baksy, as well as many epic poems and national poems". Professor K.Maksetov wrote down himself the poem "Ashik Najep" from baksi Karajan in 1960 and this version is kept in the manuscript collection in the Karakalpakstan filial of Science academy of Uzbekistan. Because Karakalpak version of the epic poem was played by Karajan baksy. Afterwards, Karakalpak baksys played the epic poem «Ashyk-Najep» among people and tried to form and change it by their repertoire. Nowadays, beloved song called «Kyz Mynayim» among Karakalpaks is sung mostly by baksys and singers. This song mainly portrays the character of Mynayim(girl) who is one of the main characters of the epic poem «Ashyk-Najep». It is marked that Karakalpak version of the epic poem is close to lyric-epic poems on its genre peculiarities.

At the present time, it is not a mistake to say that it is very important to print 100 tomes of "Karakalpak folklore", collect Karakalpak national oral works in one place and represent them to readers' community. The epic poem «Najep uglan» was also publicized in the 2742th tomes of these 100 tomes. The text of the epic poem mixed kissa and nazm was fully depicted in this book. The events in the epic poem begin with emerging of Adam ata and pyr of music of art Ashyk Aydin. It is stated at the beginning of the poem that the events in the epic poem take place in the town of Genjekarabak and events relevant to this land's king Adilkhan. 
The marriage of the protagonist of the oral epic to the widower Sona who lives in Genjekarabak's homeland is the cause of the event's beginning. Sona's little baby Nejep uglan's bringing up and becoming musician is the basement of plot'sdevelopment of the event. That is why, confusing relation between Nejep uglan and Albend as well as being professional help him cope with all of the difficulties.

The composition of the oral epic "Najep uglan" which was written in "Karakalpak folk" shows the whole mixed text of the prose and poet.

According to scientific and literal sources, a manuscript sample of Turkmen version of "Ashyk Najep» was not kept. The role of the baksy's was great to create the Turkmen version of the oral epic. For instance: there were some people who told the oral epic Nejep uglan's Turkmen version such as Mammedanna Sopiev, Nuri Khalykov, Artyk Durdiyev, Ure Seytmadov, Ure Kabaev, Gylych Odaev and so on. Kakabay Seyitmuratov mentioned that works on writing the oral epic «Nejep Uglan» from the baksys' in Turkmen were done from 1939.

Commenting on the Turkmen versions of the epic "Ashyq Najep", S.Gutlyeva noted that the epic is widespread in the southern regions of Turkmenistan, and the version performed by the famous baksy (the person who tells oral epic) Mammetanna bakhshi emphasizes that it is mature. The publication also admits that it prepared a version of the epic performed by Mammetanna Baksy.

When the oral epic is told by baksys, some differences will be visible. Right, the plot of all the versions are similar but, they are different by size.K.Seyitmuratov took into consideration such kind of differences and mentioned that: "the version of M.Sopiev is the first, N.Khalykov's is the second, U.Kabaev's is the third, U.Seytmadov's if the fouth, A.Durdiyev`s and G.Ogaev`s are the next places».

S. Gutlyeva notes that there are also impartial versions of the epic "Ashyk Najep", emphasizing that it is connected with the events of the epic "Ashyk Albent". In fact, it is known that the content of the epic "Ashyk Albent" is associated with the art of music and baksyshylyk(the art of telling oral epics by baksy). And the protagonists and characters in it are involved in both epics, but their differences are reflected in the motives, episodes, narration of the story. According to the researcher $\mathrm{S}$. Gutlyeva, the version of the epic "Ashyk Albent" written by B.Akhundov and $A$.Meredov is preserved in the manuscript fund of the Institute of Language and Literature named after I.A.Maktymkuly of Turkmenistan (inv.1382) is a manuscript written in the years 1917-1918. It states that the manuscript became known to the literary community in the 1950s. S. Gutlyeva also argues that the epic "Najep oglan" is a continuation of the epic "Ashyk Albent". In fact, there are similarities in the plot of these two epics. When we compare the versions of these two epics in the Turkic peoples, including the Uzbek and Karakalpak versions, they have similarities and differences. For example, the events in the Uzbek epic "Ashyk Albent" are slightly different from the Turkmen and Karakalpak versions. In the Uzbek version of the epic "Ashyk Albent" in the first volume of the book "Oshiknoma", so called, "Khorezm Dostonlari" (Urgench, 2005) by Professor S.R.Ruzimboev, Albend was supported by the Ashyk Aydin from the birth to his adulthood. Also, at the end of the epic, Albent marries to Sona girl and achieves his goal. In the Turkmen version, Albent's 
marriage to Sona is narrated in the epic "Ashyk Najep". At the same time, Albent and Najep's ideas merged about fathers and sons and the art of baksyshylyk. But when we compare the images in the two epics, we can see the similarity in them. For example, in the Uzbek version of the epic "Ashyk Albent" the participation of the Pir Ashyk Aydin, Albent, King Shamsikamar, Gulesrar, fairies and others heroes and characters also appear in the Turkmen versions of the oral epic. In both versions of the epic, the Ashyk Aydin supports Albent. However, the Uzbek version of the saga is dominated by mythological concepts and demonological images. In other words, even when Albent is in a difficult situation, he is first and foremost helped and supported by the Ashyk Aydin. Albent was also taken care of "erenler" and "qiriq shiltenler". At the end of epic, Albent's marriage to Sona is also attended by "qiriq shiltenler", that is, in the dream motif of the epic, Albent sees Sona in a dream, and episodes of "qiriq shiltenler" marry him to Albent. These episodes are not in the Turkmen version. In the Turkmen version of the saga, only Ashyk Albent marries Gulesrar, and the story is over. As for the Karakalpak version of the epic "Ashyk Najep", Turkmen baksys played an important role in the spread of this epic to the Karakalpak people. In the work of professor K.Maksetov called "Qaraqalpaq xaliq awizeki do'retpeleri” (Karakalpak national oral works)(Nukus, 1996) in Karakalpak folklore, it was mentioned that the poem was particularly about baksys. It states that "The epic must have spread among the Karakalpaks in the early nineteenth century, and the source of the spread is undoubtedly Turkmen baksys. During this period, Turkmen and Karakalpak baksys, who worked together in Tashavuz and Gone Urgench, on the one hand, and had strong ties, on the other, played a key role in this collaboration. In the Karakalpak version of the epic, the events of the epics "Ashyk Albent" and "Ashyk Najep" are combined and told as one epic, in other words, at the beginning of the epic "Ashyk Najep", and the events in both epics are given in the same epic plot. It should be noted that when we talk about the plot of the epics "Ashyk Najep" and "Ashyk Albent", the wide description and narration of the events in their Uzbek versions differed from the Karakalpak version of the epic. However, the most common versions of the epic in the Khorezm lowlands bear similarities with the Turkmen versions. The language of the oral epic, the system of images, motives and so on are very similar. That is, it is known that the narrative language of the Khorezm epic "Ashyk Najep" is Oghuz, in which the influence of the Turkmen language prevails.

\section{DISCUSSION AND RESULTS}

At present, the tradition of folk baksyshylyk is widely developed and continues in Turkmenistan. For example, the epic "Ashyk Najep" is performed up to the present time in the repertoire of famous baksys Kerven Yovbasarov (2018), baksy women Almagul Nazarova (2019) and Sultanbagt Rezhepova (2020). If we compare the repertoire of these baksys, it becomes clear that the version performed by the baksy Kerven Yovbasarov in 2018 is similar to the version of the oral epic Mammedanna Sopyev. And in 2019, the version performed by Almagul Nazarova will be different. For example, the beginning episodes of an epic make a difference. There are also differences in the repertoire of the baksy Sultanbagt Rezhepova of the oral epic "Nejep oglan" performed in 2020. For example, in her repertoire, Sultanbagt Rezhepova performs episodes of the oral epic, in which he became a disciple of the Ashyk Aydin, studied for seven years and tried to 
return to his homeland with the permission of his teacher. It should be noted that the version of the epic "Ashyk Najep" in the repertoire of Sultanbagt Rezhepova is briefly described.

The book "Ashyk Najep" by H.G. Korogly "Shaxsenem and Garyp, Kasym-oglan y drugye turkmenskye narodnye povesty" was published, along with other epics, the epic "Ashyk Najep" was translated into Russian. This Russian translation of the epic was published in 1991 by Nauka Publishing House in Moscow. The book includes the epics "Gaukhar kyz and Shiraly Beg", "Gul-Senuber", "Asly-Kerem", "Seipelmelek-Medhalzhemal", "Kasymoglan", "Shabahram", "ShahsanemGarib", "Yusup-Zulaikha". The translation of the epic "Nejep oglan" is given. The book was written by H.G. Koroglu. He wrote that the tradition of bakhsyshylyk was widely developed among the Turkmen people, and that good examples of this tradition are described in the epic "Ashyk Najep", in which the teacher-apprentice, that is, the music teacher, describes through the image of Ashyk Aydyn. The epic "Ashyk Najep" was also studied by representatives of Turkish folklore. For instance, Shahin, H. Ibrahim (2007) in his article “Neç Oglan Destanı'nda Türkmen Bahşıların Eğitimleri ve Executive Ortamları", he expressed his views on the art of bakhsyshylyk. Later, Şahin, H. Ibrahim wrote his doctoral dissertation entitled "Turkmenistan saha destancilik geleneği ve türkmen destanlari" (Turkey, 2009), in which he also expressed his views on the idea and content of the epic "Ashyk Najep". The author emphasizes that the epic is dedicated to the art of music, but differs from other Turkic epics. Also, in his dissertation, Shahin, $\mathrm{H}$. Ibrahim translated the epic "Ashyk Najep" into Turkish and quoted its Turkmen text in parallel with the translated Turkish text. In the book to the Turkmen version of the epic "Ashyk Najep" by Memmedanna Sopievwas translated into Turkish. Literary translation combines the experiences of aesthetics, spirituality, psyche, philosophy and logic. It highlights the common direction of interlingual genetic relations, the content of educational regulations and the closeness of guiding principles. Mainly, the desire to translate an artistic work into a native language depends on the degree to which the differences in worldview are interconnected. In it, the spirit-scale of the national image tends to create universal content characters, in which the similarity of literary norms creates a typological connection, in which the national style and the dimension of national thought are intertwined. The combination of tradition and practice determines its effectiveness.

\section{CONCLUSION}

The scale of social events, the contradictions of the spirit of the epoch, first of all, are more noticeable in the spiritual world. Socioeconomic, political and cultural changes translate from the national dimension to the values of humanity. Literary text, as well as being a personal, social and national value, retains its meaning when translated into another language. The passage of time, the renewal of thinking, shapes the interlinguistic relationship. The artistic development of this idea, the history of the growth of the human worldview, the process of creating the necessary changes in consciousness and emotions are highlighted. There is a desire for a literary translation of the epic "Ashyk Najep" into Russian and Turkish, which, firstly, led to the spread of the epic among the peoples of the world, and secondly, the national content of the epic, in which the national traditions of the people are known in the native language 
created an opportunity. Thirdly, it is one of the factors that show that in the folklore of the Turkic peoples the tradition of epos has been widely developed since ancient times.

In general, the plot of the epic "Open Najep" is widespread among the Turkic peoples, in the content of the poem there is love, generosity, patience, diligence, love of music and the art of bakhsyshylyk, a love epic poem that illuminates the people's love for music, and has survived to this day through the repertoire of bakhsys.

\section{REFERENCES}

1. Gutlyeva S. Nejep-oglan poem. Charzhev, 1990.

2. Maksetov K. "Karakalpak khalkinin korkem auzeky doretpelery". -Nukus. "Bilim", 1996.

3. Karakalpak folklore. Multi-volume. Volumes 27-42. Nukus, Ilym. 2011.

4. Korogly H.G. "Shakhsenem and Garyp", "Kasym-oglan y drugye turkmenskye narodnye povesty" -M .: Nauka, 1991

5. The poem "Nejep oglan". Ashgabat, Turkmenistan, 1977.

6. Ahyknama. Urgench, 2009. B-7

7. Şahin, H. Ibrahim (2007). “Necep Oglan Destanı'nda Türkmen Bahşılarının Eğitimleri ve İcra Ortamları", Milî Folklor, 76, Kış, 210-217. http://katalog.tdk.gov.tr/ 